\title{
KARAKTERISTIK PARAMETER POPULASI IKAN SIRO (Amblygaster sirm, CLUPEIDAE) DAN MODEL TERAPAN BEVERTON DAN HOLT DI LAUT NATUNA DAN SEKITARNYA
}

\author{
Suherman Banon Atmaja*) dan Duto Nugroho*")
}

\begin{abstract}
ABSTRAK
Pengumpulan data dari kegiatan penelitian sumber daya perikanan pelagis kecil di Laut Natuna dan sekitarnya telah dilaksanakan selama periode 1997-1999. Data bobot dan frekuensi panjang ikan dikumpulkan dari hasil tangkapan kapal pukat cincin yang melakukan penangkapan komersial atas berbagai jenis ikan. Hasil penelitian menunjukkan rata-rata ukuran ikan yang tertangkap lebih menggambarkan struktur populasi yang berada di daerah penangkapan daripada selektivitas jaring pukat cincin. Dengan nilai parameter pertumbuhan (K), mortalitas alami (M), dan ukuran pertama kali tertangkap (LC) yang relatif tinggi diperoleh kurva hubungan antara YPR (Yield per Recruit) dengan tingkat eksploitasi (E) atau mortalitas penangkapan (F) yang bersifat asimptotik, dan $E_{\max }$ atau $E_{M S Y}$ tidak dapat ditentukan. Status tingkat eksploitasi ikan siro ( $A$. sirm) masih lebih kecil $E_{0,5}$, yaitu: nilai indeks eksploitasi $(E=0,32$ atau sekitar $32 \%)$.
\end{abstract}

ABSTRACT: Characteristics of population parameters and Beverton and Holt model of "siro" spotted sardine, Amblygaster sirm, Clupeidae in Natuna Sea and its adjacent waters. By: Suherman Banon Atmaja and Duto Nugroho

A serial data collection of research activities on small pelagic fisheries resources in the Natuna Sea carried out during 1997-1999 periods. Data weight and length frequencies of fish were collected from the catch of purse seiner. The results obtained the average length at first capture (LC) which was caught by purse seine is more describing the population structure found in the fishing ground rather than the gear selectivity. The high growth, natural mortality and Lc gave asymptotic Yield per Recruit (YPR) curve, and this means no estimate of $E_{\max }$ or $E_{M S Y}$ could be determined. Status of exploitation rate spotted sardine (A. sirm) was less than $E_{0,5}$, i.e: $32 \%$.

Keywords: $\quad$ characteristics, population, model of Beverton and Holt, spotted sardine, Natuna Sea

\section{PENDAHULUAN}

Perairan bagian selatan Laut Cina Selatan merupakan bagian dari paparan Sunda dengan ratarata kedalaman sekitar 70 meter, karakteristik hidrologisnya dipengaruhi langsung oleh sirkulasi dua angin muson (angin muson utara-timur dan selatantimur). Kedua angin muson tersebut membangkitkan perubahan pola arus, kecepatan angin, salinitas, dan produktivitas primer (Wyrtki, 1961). Soegiarto dan Birowo (1976) melaporkan nilai salinitas berkisar antara 30-35 per mil, salinitas di bawah 32 per mil terjadi di perairan pantai mendekati paparan Sunda, hal ini terbentuk karena pengenceran oleh Sungai Mekong, Kapuas, Musi, salinitas pada Juni-November berkisar antara 30-35 per mil dan Desember-Mei berkisar antara 30-33 per mil. Kadar forfat berkisar antara 0,4-0,8 $\mu \mathrm{g}$ at/l, sedangkan nilai klorofil a berkisar antara $0,02-0,53 \mathrm{mg} / \mathrm{m}^{3}$. Dari hasil survai akustik pada bulan April 1994 dilaporkan salinitas perairan bagian utara lebih tinggi dari pada bagian selatan. Ekspedisi Matahari pada bulan Mei 1986 melaporkan arah arus di perairan ZEE Malaysia mengalir dari utara ke selatan dan tenggara, dan salinitas berkisar antara 32,78-33,36 $\mathrm{r}^{-1}$ per mil, kandungan fosfat terlarut 1,29-1,86 $\mu \mathrm{g}$ at/l dan ratarata klorofil a $0,2434 \mathrm{mgm}^{-3}$ (Mohsin, et. al., 1986).
Di perairan tropis, fluktuasi hasil tangkapan musiman ikan dan aktivitas pemijahan diasosiasikan dengan perubahan suhu atau salinitas antara musim hujan dan musim kemarau. Ikan layang diasosiasikan dengan massa air salinitas tinggi dan ikan sardine diasosiasikan dengan suhu air. Stok ikan pelagis sangat peka terhadap perubahan lingkungan, terutama penyebaran salinitas, pada tahun basah (curah hujan di atas normal) akan mengurangi penetrasi ikan-ikan yang bersifat oseanik ke Laut Jawa (Potier,1998). Puncak pemijahan ikan pelagis di Laut Cina Selatan berlangsung pada bulan FebruariMaret dan bulan Agustus-Nopember (Bhatiyasevi, 1997). Hasil kajian aspek reproduksi, sebagian besar ikan siro yang tertangkap masih belum matang seksual. Sedikitnya individu ikan yang matang seksual dan pemijah dalam sampel hasil tangkapan (Atmaja et al., 2001).

Permasalahan adalah kegiatan pencatatan data "catch-effort" yang sulit dimonitor, karena sebagian besar mereka menggunakan kapal angkut dan mendaratkan hasil tangkapannya di masing-masing tangkahan, banyak hasil tangkapan didaratkan di tempat lain (Tegal/Pekalongan, Palembang dan Tanjung Balai Karimun). Data statistik hasil tangkapan menurut spesies yang tidak akurat, ikan layang

\footnotetext{
") Peneliti pada Balai Riset Perikanan Laut, Jakarta

*) Peneliti pada Pusat Riset Perikanan Tangkap, Jakarta
} 
(Decapterus spp.) sebagai komponen utama sumber daya ikan pelagis kecil belum tercatat dalam data statistik perikanan di Propinsi Kalimantan Barat (tahun 2001 telah tercatat di Kab. Sambas) dan Riau. Sedangkan berdasarkan data statistik perikanan memperlihatkan jenis sardin (Sardinella spp.) mendominasi hasil tangkapan, dan diikuti oleh kelompok jenis banyar/kembung (Rastrelliger spp.) (Mertha \& Nurhakim, 1995). Perikanan pukat cincin yang beroperasi di Laut Natuna dan sekitarnya didukung oleh ikan pelagis, terutama ikan layang (Decapterus russelli dan D. macrosoma), yaitu: ratarata $67,3 \%$ dari total hasil tangkapan pukat cincin, selanjutnya diikuti berturut-turut: siro (Amblygaster sirm) memberi kontribusi sebesar $6,5 \%$, banyar (Rastrelliger kanagurta) sebesar 6,1\%, tanjan (Sardinella spp.) sebesar $5,4 \%$ dan bentong (Selar crumenophthalmus) sekitar 3,6\%.

Permasalahan lainnya keikutsertaan pemanfaatan sumber daya ikan pelagis kecil di perairan ini cenderung meningkat terus. Penggunaan jumlah lampu sorot cenderung meningkat terus tanpa kendali dan pengusaha mengadopsi teknologi baru (penggunaan lampu bawah air). Peningkatan kemampuan menangkap ikan tersebut telah menyebabkan perubahan indeks upaya penangkapan. Permasalahan tersebut masih sulit didokumentasi dan disesuaikan untuk kajian pendugaan stok ikan dari model surplus produksi

Tulisan ini bertujuan untuk mengetahui parameter populasi ikan siro kaitannya dengan model terapan YPR (yield per recruit) Berverton dan Holt di Laut Natuna dan sekitarnya. Berdasarkan interaksi karakteristik parameter populasi dapat menentukan pola YPR, dan daya tahan populasi ikan terhadap tekanan penangkapan. Sebagai hipotesis pada penelitian ini adalah karakteristik parameter populasi dan rata-rata ukuran ikan siro yang tertangkap akan menentukan daya tahan populasi ikan terhadap penangkapan.

\section{BAHAN DAN METODE}

Data frekuensi panjang ikan diperoleh selama tahun 1997-1999. Pengambilan contoh diambil langsung dari palka yang dilakukan setiap hari pada kapal yang berbeda, secara acak berlapis menurut waktu dan daerah penangkapan. Contoh ikan diambil sebanyak satu basket, kemudian disortir dan dihitung jumlahnya menurut jenis ikan. Contoh ikan yang diukur panjangnya sebanyak 50 ekor per basket sesuai dengan Boely et. al., (1990); Potier dan Sadhotomo (1991)

Data frekuensi panjang dari gabungan daerah penangkapan (Kep. Natuna, Midai, Serasan, P. Tambelan, P. Tarempa, dan P. Pejantan) diaplikasikan untuk perkiraan rata-rata ukuran ikan yang tertangkap, pendugaan parameter pertumbuhan $(K, L \infty)$ dan mortalitas dengan mengunakan paket program FISAT. Sebagai pembanding dilakukan pendugaan (K) melalui nilai rata-rata indeks (Pauly \& Munro, 1984), sebagai berikut:

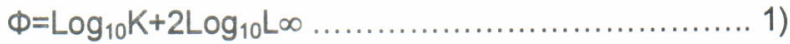

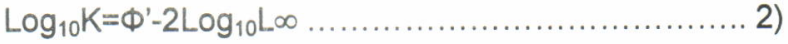

di mana:

$\Phi=$ perkiraan distribusi normal untuk satu spesies pada perairan berbeda

$\Phi^{\prime}=$ rata-rata nilai $\Phi$

Mortalitas alami (M) dihitung dengan rumus empiris Pauly, sebagaimana diketahui ikan siro mempunyai sifat bergelombol maka nilai M mengikuti persamaan:

$M=0,8 \operatorname{Exp}\left(-0,01520,279^{*} \operatorname{LnL} \infty+0,6543^{*} \operatorname{LnK}+0,463^{*} \operatorname{LnT} \ldots .3\right)$

di mana:

\section{$T=$ temperatur perairan}

Rata-rata ukuran ikan yang tertangkap diturunkan dari $50 \%$ kumulatif frekuensi sebaran ukuran, Sedangkan hubungan panjang-bobot ikan dihitung berdasarkan persamaan:

$W=a^{*} L^{b}$

Untuk mengetahui nilai $b=3$ dilakukan $t_{\text {test. Jika }}$ hasil uji $t$ diperoleh nilai $b=3$, maka nilai $b$ dapat dipatok $=3$ dengan konstanta a yang diubah menjadi:

$$
a=E X P\left(Y-3^{*} X\right)(B a y e r, 1987)
$$

Untuk mengetahui pengaruh karakteristik parameter populasi terhadap respon tekanan penangkapan, menggunakan YPR (Yield per recruit) Beverton \& Holt:

$Y_{P R}$ relatif $\left.=E^{\star} U^{M / K_{*}}\left[1-3 U /(1+m)+3 U^{2} /(1+2 m)-U^{3} /(1+3 m)\right] \ldots .6\right)$

Atau

YPR $=F^{*} R^{*} E X P\left[-M^{*}(t c-t r)\right]^{*} W_{\infty}^{*}\left[1 / Z-3 S /(Z+K)+3 S^{2} /(Z+2 K)-\right.$

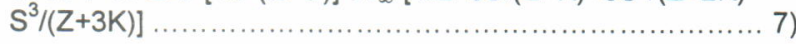

di mana:

$U \quad=1-(\mathrm{LC} / \mathrm{L} \infty)$

$\mathrm{E} \quad=\mathrm{F} / \mathrm{Z}$

$\mathrm{M} \quad=(1-\mathrm{E}) /(\mathrm{M} / \mathrm{K})$

$S \quad=E X P\left[-K^{*}\right.$ (tc-to)

$K \&$ to $=$ parameter pertumbuhan von Bertalanffy

Lo = panjang ikan asimptotik

$\mathrm{W}_{\infty}=$ bobot badan ikan asimptotik

$\mathrm{F} \quad=$ mortalitas penangkapan

$\mathrm{M}=$ mortalitas alami

$\mathrm{Z}=$ mortalitas total $(\mathrm{M}+\mathrm{F})$

LC = umur pertama kali tertangkap

$\operatorname{tr} \quad=$ umur pada peremajaan (recruitment) 


\section{HASIL DAN BAHASAN}

\section{Hubungan Panjang-Bobot}

Hasil uji $t$ terhadap b menunjukkan kisaran kepercayaan $95 \%$ adalah 2,99-3,34; berarti hubungan panjang-bobot ikan siro (A. sirm) bersifat "isometric". Dengan demikian nilai $b$ dapat dipatok $(b=3)$ dengan merubah nilai konstanta a menjadi 0,0141 (Gambar 1).
Pematokan nilai $b=3$ berkaitan dengan pertumbuhan bersih bobot seekor ikan adalah selisih dari hasil proses metabolisme (antara anabolisme dan katabolisme). Anabolisme berbanding lurus dengan luas tubuh, sedangkan katabolisme berbanding lurus dengan panjang pangkat tiga. Aplikasi nilai $b=3$ berkaitan langsung dengan penurunan model pertumbuhan von Bertalanffy dan model YPR (Yield per recruit) dari Beverton dan Holt.

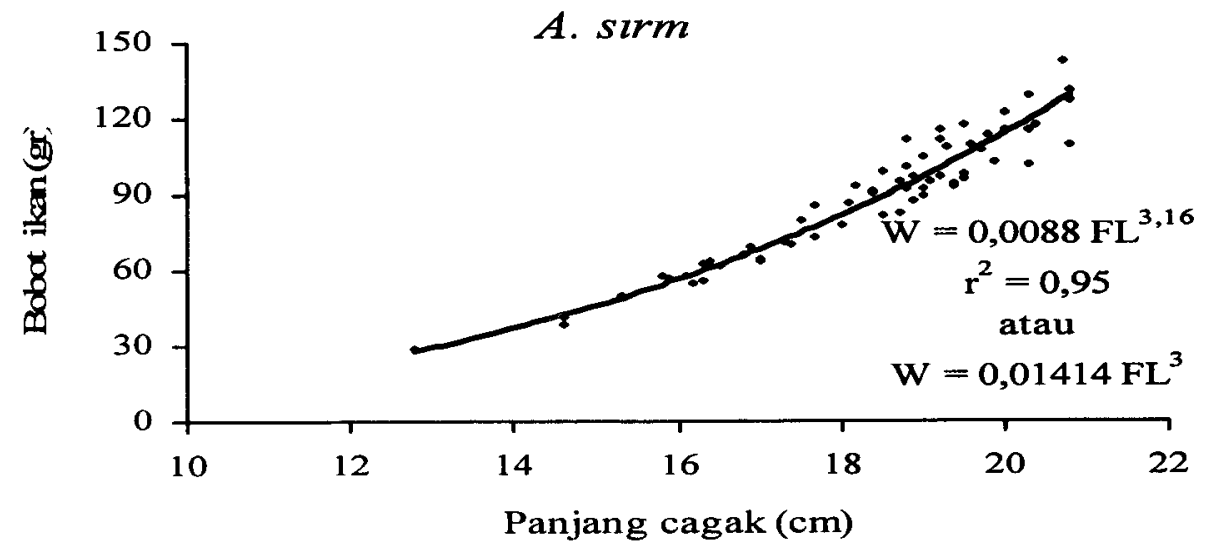

Gambar 1. Hubungan panjang-bobot ikan siro (A. sirm).

Figure 1. Length-Weight relationship of spotted sardine (A. sirm).

\section{Rata-Rata Ukuran Ikan}

Sebaran frekuensi panjang ikan siro hasil tangkapan pukat cincin umumnya mempunyai kisaran ukuran yang sempit dan hanya satu modus. Rata-rata ukuran ikan yang tertangkap (LC) dicerminkan oleh lima puluh persen kumulatif frekuensi sebaran ukuran ikan, diperoleh nilai Lc=17 cm (Gambar 2). Nilai Lc ini lebih menjelaskan struktur populasi yang ada di daerah penangkapan daripada mekanikal selektivitas dari alat tangkap pukat cincin, di mana ikan siro yang menjadi tujuan penangkapan umumnya mempunyai tendensi membentuk kawanan yang terdiri dari ikan berukuran sama, tidak semua kelas ukuran (umur) berada di daerah penangkapan. Nelayan telah mengetahui dengan baik daerah penangkapan yang menguntungkan dan biasanya memilih pada kisaran sempit dari spesies dan ukuran ikan. Berdasarkan pengamatan di lapangan, siro berukuran $8-9 \mathrm{~cm}(F L)$ tertangkap terjerat (gilled) pada bagian sayap dengan ukuran mata jaring (\# $\left.1^{\prime \prime}\right)$. Ikan yang tertangkap terjerat akan menghambat operasi penangkapan berikutnya dan ikan-ikan tersebut mempunyai nilai ekonomis rendah (Atmaja \& Nugroho, 1995).

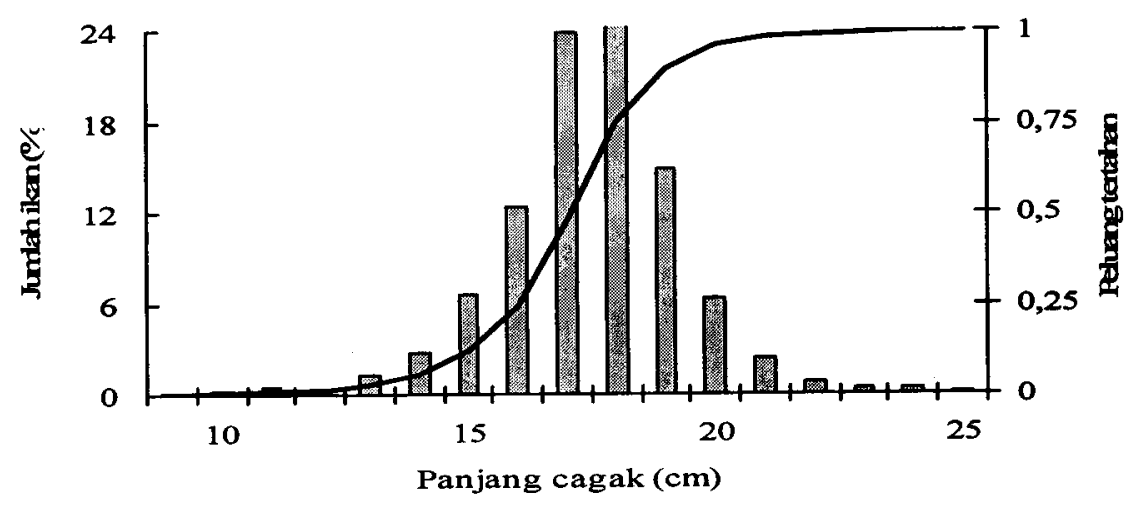

Gambar 2. Sebaran fekuensi panjang dan frekuensi panjang kumulatif hasil tangkapan ikan siro ( $A$. sirm). Figure 2. The distribution of length frequency and cumulative length frequency of caught spotted sardine (A.Sirm). 


\section{Parameter populasi}

Dari hasil analisis dengan FISAT dan empiris $\Phi$ diperoleh nilai $K$ relatif hampir sama, yaitu 0,825 $\operatorname{tahun}^{-1}$ dan 0,99 tahun $^{-1}$. Nilai-nilai parameter pertumbuhan dan mortalitas ikan siro diterakan pada Tabel 1. Hasil analisis berada pada kisaran dari variasi hasil menurut lokasi penelitian yang menggunakan empiris $\Phi$ (Tabel 2). Conand (1991) menyimpulkan bahwa ikan siro ( $A$. sirm) termasuk ikan cepat tumbuh dan berumur pendek, matang seksual pertama kali dicapai ketika umur setahun, mortalitas tinggi dan biasanya mati sebelum tahun kedua, mereka mati setelah musim pemijahan. Dari nilai Lc di atas diperkirakan bahwa ikan siro di Laut Natuna berumur $1-1,3$ tahun.

Tabel 1. Parameter pertumbuhan dan mortalitas ikan siro (A. sirm)

Table 1. Mortality and growth parameters of spotted sardine (A. sirm)

\begin{tabular}{lccccc}
\hline \multicolumn{1}{c}{ Metode } & $\Phi$ & Lo $(\mathbf{c m})$ & Z/K(tahun $\left.{ }^{-1}\right)$ & K(tahun $\left.{ }^{-1}\right)$ & M(tahun \\
\hline Powell \& Weatheall & 2,783 & 26,12 & 2,35 & & \\
Empiris $\Phi$ & & & & 0,99 & 1,6 \\
Elefan & & 26,00 & & 0,825 & 1,4 \\
\hline
\end{tabular}

Tabel 2. Parameter pertumbuhan ikan siro ari beberapa perairan berbeda Table 2. Growth parameter of spotted sardine from some different waters

\begin{tabular}{cclll}
\hline Lo $(\mathbf{c m})$ & $\mathbf{K}\left(\mathbf{t h}^{-1}\right)$ & \multicolumn{1}{c}{ Lokasi/Location } & Metode & Ref. \\
\hline 22,6 & 0,65 & Al Ghardaqa, Red Sea Egypt & Elefan I & Pauly (1978) \\
25,8 & 1,15 & Laut Jawa, 1982-1983 & Elefan I & Dwiponggo et al (1986) \\
25,2 & 1,18 & Laut Jawa & Elefan I & Sadhotomo and Atmaja (1985) \\
23,3 & 1,3 & Laut Jawa,1992-1993 & Elefan I & Suwarso et al (1995) \\
24,3 & 0,59 & Jakarta Bay, Java Sea & Elefan I & Pauly (1978) \\
26 & 0,825 & Laut Jawa,1992-1993 & Elefan I & Sadhotomo (1998) \\
25,5 & 0,8 & Laut Jawa,1993-1994 & Elefan I & Sadhotomo (1998 \\
25,3 & 0,65 & Laut Jawa, 1994-1995 & Elefan I & Sadhotomo (1998 \\
23,2 & 1,1 & St. Vincent, New Caledonia, 1980-1982 & Others & Conand (1991) \\
22,2 & 1,58 & Lagoons, New Caledonia & Others & Conand (1991) \\
21,7 & 1,35 & Dumbea Bay, New Caledonia, 1982 & Others & Conand (1991) \\
29 & 1,3 & Camote Sea, Philippines & Elefan I & Dalzell (1988) \\
27,3 & 0,86 & Palawan, Philippines, 1959 & Elefan I & Ingle and Pauly (1984) \\
25,2 & 1,25 & Western Coast, Srilangka, 1984-1987 & Elefan I & Karunasinghe and Wijeyaratme (1991) \\
\hline Sumber: Sadhotomo $(1998)$ & & & &
\end{tabular}

\section{YPR (Yield per recruit) Beverton \& Holt}

Dalam model Beverton \& Holt (Yield per recruit, YPR), pertumbuhan surplus adalah fungsi dari komposisi umur yang dieksploitasi. Penangkapan akan memperbesar mortalitas ikan dan merubah komposisi umur, sehingga kelompok ikan muda menjadi lebih banyak. Pada model tersebut, umumnya peremajaan (recruitment) tidak diketahui, dinyatakan dalam YPR, kelemahan utama tidak dapat menggambarkan penurunan peremajaan sehubungan dengan penurunan besaran stok. Berdasarkan YPR menekankan interaksi karakteristik parameter populasi mempunyai respon kuat dari suatu jenis ikan terhadap tekanan penangkapan. Selektivitas alat tangkap menurunkan hasil tangkapan bertalian dengan penangkapan yang berlebihan pada kelompok umur muda atau rata-rata ukuran ikan yang tertangkap akan semakin kecil.

Dengan nilai $K, M$, dan Lc yang relatif tinggi diperoleh kurva hubungan antara YPR dengan tingkat eksploitasi (E) atau kematian penangkapan ( $F$ ), tampak bahwa YPR mendekati tak terhingga (asimptotik) jika $E$ atau F menjadi tinggi (Gambar 3) dan $E_{\max }$ atau $E_{\text {msy }}$ tidak dapat ditentukan. Perilaku ini jelas tak mungkin untuk sistem eksploitasi sumber daya ikan yang nyata. Kematian penangkapan (F) adalah berbanding lurus dengan upaya penangkapan (f) dan kemampuan tangkap (q), yaitu: $F=q^{*} f$, artinya kenaikan $F$ akan diikuti dengan kenaikan $f$. Sedangkan $f$ sendiri akan dibatasi oleh faktor biaya eksploitasi, tingkat keuntungan, dan kenaikan upaya penangkapan yang semakin tinggi tidak akan sebanding dengan kenaikan hasil tangkapan. Karenanya untuk tujuan pengelolaan biasanya menggunakan konsep $E_{0,1}$ atau $F_{0,1}$ adalah titik di mana slope dari kurva yield sebesar 0,1 dari nilai slope pada tingkat $F$ yang rendah (nilai indeks eksploitasi tingkat laju kematian penangkapan pada kenaikan laju eksploitasi sebesar $10 \%$ dari awal usaha penangkapan terhadap suatu stok ikan). Gambar 3B menunjukkan nilai $E_{0,1}(>0,9)$ atau $F_{0,1}=2,1\left(E_{0,1}>0,6\right)$ yang tidak realitis dan dapat diartikan bahwa YPR spesies tersebut akan meningkat dengan kadar menurun (deminishing rate) terjadi pada tingkat eksploitasi yang tinggi. Bagaimanapun stok ikan yang dapat dieksploitasi 
merupakan kuantitas yang dapat berubah, tergantung pada intensitas penangkapan. Semakin banyak ikan ditangkap, maka semakin sedikit stok ikan yang tersisa. Status tingkat eksploitasi untuk ikan siro $(A$. sirm) di perairan tersebut belum mencapai nilai $\mathrm{E}_{0,5}$ yaitu: nilai indeks eksploitasi yang sedang berjalan $(E=0,32$ atau sekitar $32 \%)$.

Berdasarkan perkembangan upaya penangkapan dari kapal pukat cincin yang berpangkalan di Pekalongan dan beroperasi di perairan Laut Natuna menunjukkan adanya perilaku pengusaha/nelayan mengalokasikan upaya penangkapan. Upaya penangkapan (jumlah trip dan hari operasi) selama periode tahun 1985-2003 berfluktuasi setiap tahunnya (Gambar 4). Waktu operasi penangkapan pukat cincin juga semakin lama, dari rata-rata hari operasi 21 hari/trip (tahun 1985) menjadi 50 hari/trip (tahun 2003).

Beberapa hasil analisis memberikan indikasi tentang reaksi tekanan penangkapan dari beberapa jenis sumber daya ikan pelagis kecil $(D$. russelli, $D$. macrosoma, $R$. kanagurta, S. lemuru), maksimum YPR akan terjadi pada tingkat mortalitas penangkapan yang tinggi dan ikan muda. Perikanan tipe ini mempunyai juga sifat cepat pulih dari lebih tangkap. Namun demikian, perhatian harus diberikan terhadap masalah fluktuasi alami kelimpahan, sebagaimana diketahui ikan siro sangat peka oleh perubahan kuat fisik lingkungan. Perubahan lingkungan, terutama anomali lingkungan selain akan mempengaruhi proses biologi, juga akan menyebabkan runtuhnya perikanan akibat kegagalan peremajaan (recruitment), terutama pada kelompok ikan Clupeidae (anchovy di perairan Peru, sardine di beberapa perairan) (Cushing dalam King, 1998). Raja dalam Longhust \& Pauly (1987) menyatakan bahwa ikan Sardinella longicep di perairan Teluk Bengala, pada curah hujan kurang dari $10 \mathrm{~mm}$ di bulan Juni akan menyebabkan ovarium ikan tersebut gagal berkembang (atresia). Nagasaki dan Chikuni (1989) menyetujui bahwa gejala fluktuasi tahunan berkaitan dengan keberhasilan dan kegagalan pemijahan, perkembangan dan pertumbuhan telur dan juwana, sehingga mengakibatkan penurunan dan kenaikan satu generasi. Laevastu (1993) mempostulasikan bahwa fluktuasi klimatologis berdampak terhadap daur hidup dari ikan pelagis yang bersifat neritik dan oseanik.
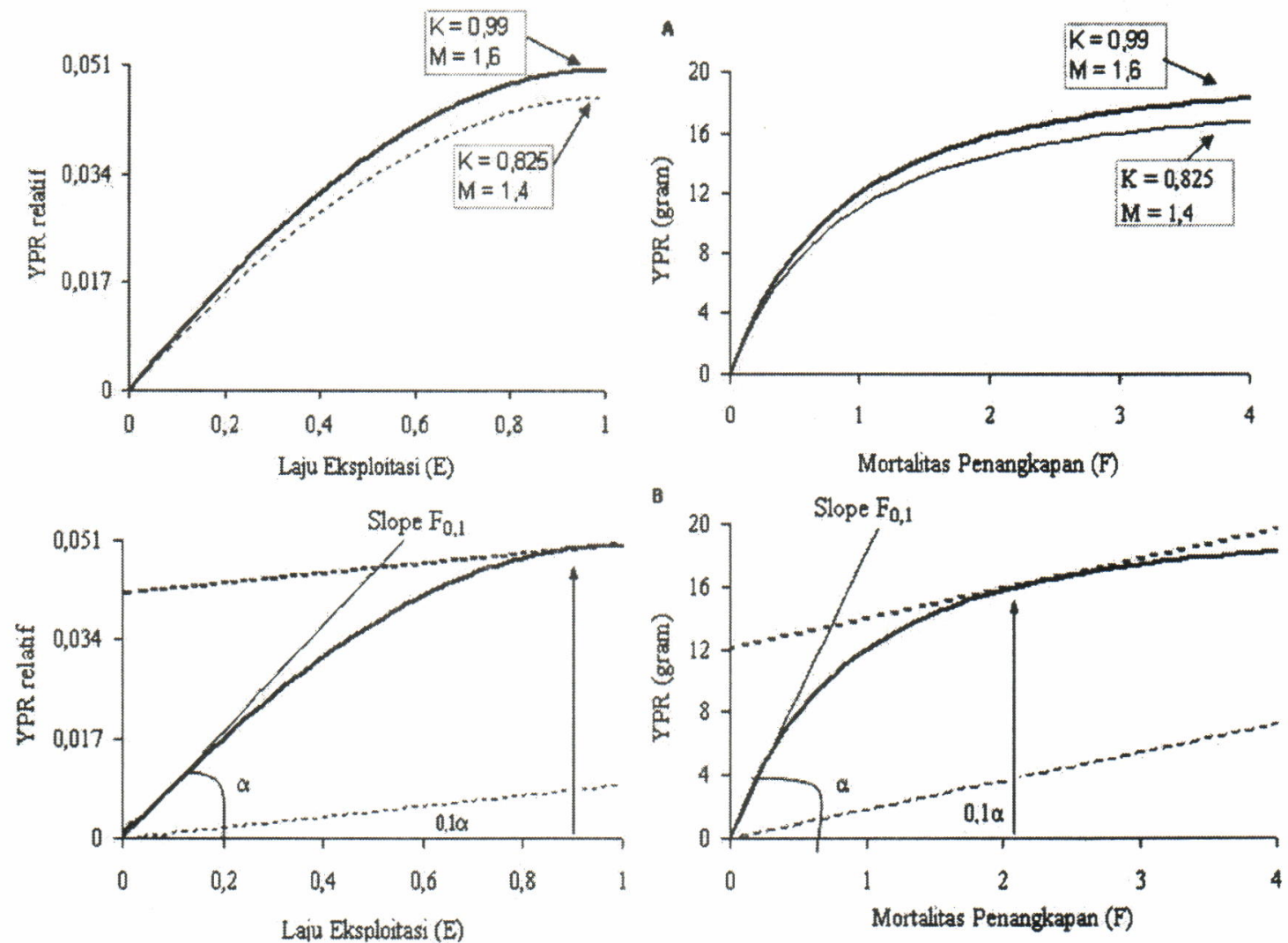

Gambar 3. A. Kurva YPR ikan siro (A. sirm), B. Pendugaan nilai $\mathrm{E}_{0,1}$.

Figure 3. A. YPR curve of spotted sardine (A.sirm). B. The estimated of $E_{0,1}$ 


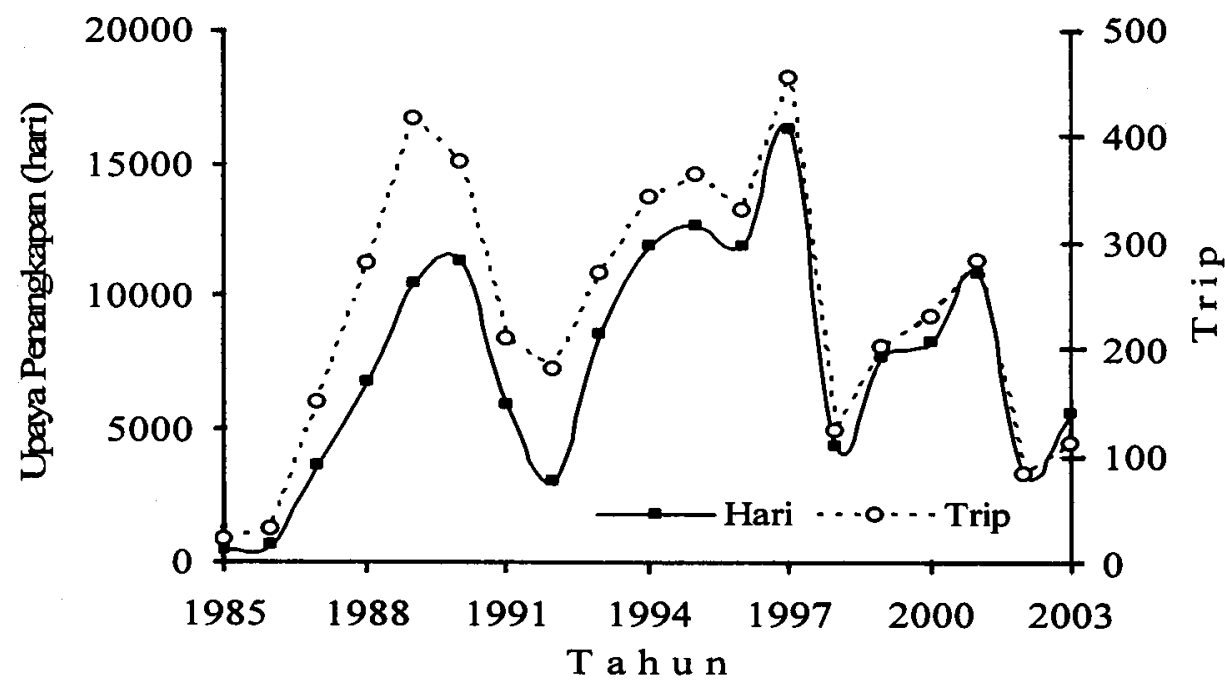

Gambar 4. Perkembangan upaya penangkapan pukat cincin Pekalongan di Laut Natuna dan sekitarnya. Figure 4. Cacth effort developing of Pekalongan purse seine in Natuna sea and its adjacent.

\section{KESIMPULAN}

Nilai $K, M$, dan Lc yang relatif tinggi menghasilkan YPR relatif yang bersifat asimptotik, $E_{\max }$ atau $E_{M S Y}$ tidak dapat ditentukan. Nilai $E_{0,1}(>0,9)$ atau $F(>2)$ menunjukkan nilai yang tidak realitis dan dapat diartikan bahwa siro termasuk spesies ikan yang dapat dieksploitasi dengan upaya penangkapan yang tinggi.

Pada dasarnya kenaikan upaya penangkapan akan dibatasi oleh faktor biaya eksploitasi, tingkat keuntungan dan kenaikan upaya penangkapan yang semakin tinggi namun tidak akan sebanding dengan kenaikan hasil tangkapan.

Status tingkat eksploitasi untuk ikan siro ( $A$. sirm) di perairan tersebut belum mencapai $E_{0,5}$, di mana: nilai indeks eksploitasi yang sedang berjalan yaitu $E=0,32$ atau sekitar $32 \%$.

\section{DAFTAR PUSTAKA}

Atmaja, S.B. \& D. Nugroho. 1995. Aspek reproduksi ikan layang deles (Decapterus macrosoma) dan siro (Amblygaster sirm) sebagai pertimbangan dalam pengelolaannya di Laut Jawa. Jurnal Penelitian Perikanan Indonesia. Vol I (3):1-10.

Atmaja, S.B; E. S. Wiyono, \& D. Nugroho. 2001. Karakteristik sumber daya ikan pelagis kecil di Laut Cina Selatan dan perkembangan eksploitasinya. Buletin PSP. Vol 1 (7).

Bhatiyasevi, U. 1997. Marine resources and fisheries in the exclusive economic zones of Thailand. In: Fishery resources and state of stocks exploitation in the waters of Gulf of Thailand, East coast of peninsular Malaysia and Andaman Sea. Training Department. SEAFDEC. $90 \mathrm{p}$.

Bayer, J.E. 1987. On length-weight relationships. Part I: Computing the mean weight of fish in a given length class. Fishbyte. ICLARM. Vol: 5(1):11-13.

Boely, T.; M. Potier \& S. Nurhakim, 1990. Study of the big purse seines fishery in the Java Sea. (VI. Sampling). Jurnal Penelitian Perikanan Laut. 56: 1-12.

Chullasorn. S. 1997. Review of small pelagic resources and their fisheries in the Gulf of Thailand. In Devaraj, M. \& P. Martosubroto (Eds.): Small pelagic resources and their fisheries in the Asian-Pacific region. Proceeding of APFIC working party on marine fisheries, 13-16 May 1997. Bangkok, Thailand. RAP Publication. 1997/31. 337-364.

Conand, F. 1991. Biology and phenology of Amblygaster sirm (Clupeidae) in New Caledonia, a sardine of the coral environment. Bull. Mar. Sci. 48 (1): 137-149.

Ean Chee, P. 1997. Small pelagic fish resources and their fisheries in Malaysia. In Devaraj, M. \& P. Martosubroto (Eds.): Small pelagic resources and their fisheries in the Asian-Pacific region. Proceeding of APFIC working party on marine fisheries, 13-16 May 1997. Bangkok, Thailand. RAP Publication. 1997/31. 244-258.

King, M. 1998. Fisheries biology, assessment and management. Fishing New Books. England. 338 p. 
Laevastu, T. 1993. Marine climate weathers and fisheries. Fishing New Books. England. 205 p.

Longhust, A.R. \& D. Pauly. 1987. Ecology of tropical oceans. Academic Press Inc. New York. 407 p.

Mertha, I.G.S. \& S. Nurhakim. 1995. The development of marine fishery in the South China Sea area of Indonesia. Country Status Report. The Second Regional Workshop on Shared Stocks in the South China Sea Area. Kuala Trengganu Malaysia 18-20 July 1995. SEAFDEC/MFRDMDMS/95/CR 6. 9198.

Mohsin, A.Kh. M.: R.A. Rahman \& M.A. Ambak. 1986. Ekspedisi matahari' 86. A study on the offshore waters of the Malaysian EEZ. Faculty of Fisheries \& Marine Science, University Pertanian Malaysia. Occassional Publication No. 4. 197 p.

Nagasaki, F. \& S. Chikuni. 1989. Managemeni of multispecies resources and multigear fisheries. Fisheries Technical Paper 305. FAO. United Nations Rome. 68 p.

Pauly, D. \& J.L. Munro. 1984. Once more on the comparison of growth in fish and invertebrates. Fishbyte 2(1):14-19.
Potier, M. \& B, Sadhotomo 1991. Sampling training. ALAINS/87/17. Scien. and Tech. Doc. 4. 29 p.

Potier, M., 1998. Pêcherie de layang et senneurs semi industrie/s Javanais: Perspective historique et approche système. Phd Thesis, Université de Montpellier II, 280p.

Sadhotomo, B. 1998. Bioécologie des principales espèces pélagiques exploitées en mer de Java. Phd Thesis, Université de Montpellier II, 364 p.

Soegiarto, A. \& S. Birowo (eds).1975. Buku I. Atlas oceanologi perairan Indonesia dan sekitarnya. LON-LIPI. Jakarta, Indonesia. 79p.

Sujastani, T. \& E.M. Amin. 1978. Kemungkinan pengembangan dan modernisasi perikanan skala kecil atau perikanan rakyat di perairan laut Cina Selatan yang termasuk kawasan Kabupaten Kepulauan Riau. Simposium Mordernisasi Perikanan Rakyat. LPPL. Litbang Pertanian. 26 p.

Sujastani, T. 1974. Dinamika populasi ikan kembung di Laut Jawa. LPPL (1): 30-64.

Wyrthi. K. 1961. Physical oceanography of the southeast Asian Water. Naga Rep. 2: 1-195. 
